\title{
Article \\ Anti-Inflammatory Effects of Compounds from Cudrania tricuspidata in HaCaT Human Keratinocytes
}

\author{
Wonmin Ko ${ }^{1,+}$, Nayeon Kim ${ }^{1,+}$, Hwan Lee ${ }^{1}$, Eun-Rhan Woo ${ }^{1}$, Youn-Chul Kim ${ }^{2}$, Hyuncheol Oh ${ }^{2,3}$ and \\ Dong-Sung Lee ${ }^{1, *(D)}$ \\ 1 College of Pharmacy, Chosun University, Gwangju 61452, Korea; rabis815@naver.com (W.K.); \\ rlaskdus1209@naver.com (N.K.); ghksdldi123@hanmail.net (H.L.); wooer@Chosun.ac.kr (E.-R.W.) \\ 2 Institute of Pharmaceutical Research and Development, College of Pharmacy, Wonkwang University, \\ Iksan 54538, Korea; yckim@wku.ac.kr (Y.-C.K.); hoh@wonkwang.ac.kr (H.O.) \\ 3 Hanbang Cardio-Renal Syndrome Research Center, Wonkwang University, Iksan 54538, Korea \\ * Correspondence: dslee2771@chosun.ac.kr; Tel.: +82-62-230-6386; Fax: +82-62-222-5414 \\ + These authors contributed equally to this work.
}

Citation: Ko, W.; Kim, N.; Lee, H.; Woo, E.-R.; Kim, Y.-C.; Oh, H.; Lee, D.-S. Anti-Inflammatory Effects of Compounds from Cudrania tricuspidata in HaCaT Human Keratinocytes. Int. J. Mol. Sci. 2021, 22, 7472. https://doi.org/10.3390/ ijms22147472

Academic Editor: Maurizio Battino

Received: 28 May 2021

Accepted: 10 July 2021

Published: 12 July 2021

Publisher's Note: MDPI stays neutral with regard to jurisdictional claims in published maps and institutional affiliations.

Copyright: (c) 2021 by the authors. Licensee MDPI, Basel, Switzerland This article is an open access article distributed under the terms and conditions of the Creative Commons Attribution (CC BY) license (https:// creativecommons.org/licenses/by/ $4.0 /)$

\begin{abstract}
The root bark of Cudrania tricuspidata has been reported to have anti-sclerotic, antiinflammatory, antioxidant, neuroprotective, hepatoprotective, and cytotoxic activities. In the present study, the effect of 16 compounds from C. tricuspidata on tumor necrosis factor- $\alpha+$ interferon- $\gamma$ treated HaCaT cells were investigated. Among these 16 compounds, 11 decreased IL- 6 production and 15 decreased IL-8 production. The six most effective compounds, namely, steppogenin (2), cudraflavone C (6), macluraxanthone B (12), 1,6,7-trihydroxy-2-(1,1-dimethyl-2-propenyl)-3methoxyxanthone (13), cudraflavanone B (4), and cudratricusxanthone L (14), were selected for further experiments. These six compounds decreased the expression levels of chemokines, such as regulated on activation, normal T cell expressed and secreted (RANTES) and thymus and activationregulated chemokine (TARC), and downregulated the protein expression levels of intercellular adhesion molecule-1. Compounds 2, 6, 12, 4, and 14 inhibited nuclear factor-kappa B p65 translocation to the nucleus; however, compound 13 showed no significant effects. In addition, extracellular signal regulatory kinase-1/2 phosphorylation was only inhibited by compound 14, whereas p38 phosphorylation was inhibited by compounds $\mathbf{1 3}$ and $\mathbf{4}$. Taken together, the compounds from $C$. tricuspidata showed potential to be further developed as therapeutic agents to suppress inflammation in skin cells.
\end{abstract}

Keywords: Cudrania tricuspidata; inflammation; ICAM-1; NF-кB; HaCaT

\section{Introduction}

Cudrania tricuspidata Bureau (Moraceae) is a tree that is found in China, Korea, and Japan. Its root has been used in traditional medicines in Korea and China [1]. C. tricuspidata is a red apricot that blooms in June and ripens between September and October [2]. Approximately 10 species of Cudrania have been identified. These species grow in the wild throughout Korea. The bark of $C$. tricuspidata is grayish brown, its deformed branches have thorns whose length ranges from 0.5 to $3.5 \mathrm{~cm}$, and its trunk has hairs. Its old bark has a yellowish-gray color and is torn vertically [3], and its leaves are split in three. Furthermore, the edges of the leaves are flat and egg-shaped, and both shapes are found on a single tree [4]. C. tricuspidata can be used throughout the year. In fact, its roots and leaves contain active pharmaceutical substances that exhibit anticancer, antioxidant, and hypoglycemic effects [5]. The root bark of C. tricuspidata has also been reported to exhibit anti-sclerotic [6], neuroprotective [7], anti-inflammatory [8], mast cell activation [9], cytotoxic [10], pancreatic lipase inhibitory [11], and monoamine oxidase suppressive effects [12]. Several parts of $C$. tricuspidata have been studied regarding their phytochemical characterization, standing out its abundancy on phenolic compounds, especially flavonoids. In this regard, flavanone, 
flavonol, flavonol glycoside, flavanone glycoside, and xanthone were already reported by different studies highlighting the antioxidant potential of the phenolic-rich extracts obtained from C. tricuspidata samples [13-21]. Keratinocytes are known to play an important role in inflammation [22]. Keratinocytes secrete various cytokines and chemokines, causing a local inflammatory reaction [23]. In fact, many skin diseases, such as allergic contact dermatitis, psoriasis, and atopic dermatitis, are related to inflammation. Dermatitis is affected by genetic, environmental, and immunological disorders, while chronic inflammation is characterized by increased epidermal thickness and the infiltration of macrophages, mast cells, and other inflammatory cells [24]. The stimulation of keratinocytes by tumor necrosis factor $\alpha(\mathrm{TNF}-\alpha)$ and interferon $\gamma(\mathrm{IFN}-\gamma)$ is highly dependent on their activation and this stimulation induces the expression and secretion of chemokines, such as regulated on activation, normal $\mathrm{T}$ cell expressed and secreted (RANTES) and thymus and activationregulated chemokine (TARC), which are regulated accordingly. These factors contribute to the recruitment and infiltration of inflammatory cells in the skin [25]. The stimulation of keratinocytes by TNF- $\alpha$ and IFN- $\gamma$ induces the expression of pro-inflammatory cytokines, such as IL- 6 and IL-8. These cytokines and chemokines contribute to the infiltration of inflammatory cells into inflamed areas of the skin [26]. Mitogen-activated protein kinases (MAPKs) are important enzymes in cell signaling, apoptosis, carcinogenesis, and the pathogenesis of different diseases [27]. MAPK is a serine/threonine kinase that comprises the following subfamilies: extracellular signal regulatory kinase (ERK), p38 kinase, and c-Jun $\mathrm{N}$-terminal kinase (JNK) [28]. MAPK activation can cause the translocation of c-Fos or c-Jun to the nucleus, where it activates transcription factors via phosphorylation, ultimately causing gene expression changes [28]. Nuclear factor-kappa B (NF-KB) is one of the most important transcription factors that translocates to the nucleus upon activation and causes genetic modifications [29]. After NF- $\mathrm{KB}$ translocates to the nucleus, it binds to its DNA recognition element and activates the transcription of its target gene [30]. NF- $\mathrm{kB}$ participates in the regulation of various biological processes, such as immune response, cell growth, and apoptosis. The five well-known mammalian NF- $\mathrm{kB} /$ Rel proteins are Rel (c-Rel), p65 (RelA), RelB, p50 (NFkB1), and p52 (NFkB2) [30]. NF-kB activation induces a high rate of IKB phosphorylation and proteolysis by IкB kinase (IKK) [30]. Furthermore,

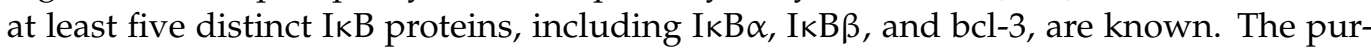
pose of this study was to investigate the effects of 16 compounds from C. tricuspidata on skin inflammation.

\section{Results and Discussion}

\subsection{Chemical Structures of 16 Compounds Isolated from C. tricuspidata}

A total of 16 compounds were isolated from the roots of $C$. tricuspidata in a previous study [31]. The chemical structures and names of the compounds are shown in Figure 1 and Table 1, respectively. C. tricuspidata extracts have been reported to have a skin inflammatory modulating effect [3]. Therefore, the inhibitory effects of IL- 6 and IL-8 production by the C. tricuspidata $70 \% \mathrm{EtOH}$ extracts were examined (Figure 2). C. tricuspidata $70 \% \mathrm{EtOH}$ extracts had a significant inhibitory effect on IL- 6 and IL-8 production against the TNF- $\alpha+$ IFN- $\gamma$ stimulation in HaCaT cells (Figure 2). Based on these results, it was concluded that there would be some compounds that had an inhibitory effect on skin inflammatory action among the compounds from C. tricuspidata. 


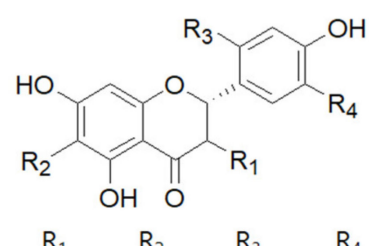

$$
\begin{array}{cccc}
\mathrm{R}_{1} & \mathrm{R}_{2} & \mathrm{R}_{3} & \mathrm{R}_{4} \\
\mathrm{OH} & \mathrm{H} & \mathrm{H} & \mathrm{H}
\end{array}
$$$$
\begin{array}{llll}
\mathrm{H} & \mathrm{OH} & \mathrm{H}
\end{array}
$$

OH CH $2 \mathrm{CH}=\mathrm{C}\left(\mathrm{CH}_{3}\right)_{2} \mathrm{OH} \mathrm{CH} \mathrm{CH}_{2} \mathrm{CH}\left(\mathrm{CH}_{3}\right)_{2}$

$4 \mathrm{H} \mathrm{CH}_{2} \mathrm{CH}=\mathrm{C}\left(\mathrm{CH}_{3}\right)_{2} \mathrm{OH} \quad \mathrm{H}$<smiles>[R2]c1c(O)c(O)cc2c(=O)c3c(O)c4c(c([R])c3oc12)C(C)(C)[C@@H](C)O4</smiles>
$\mathrm{R}_{1} \quad \mathrm{R}_{2}$ $\mathrm{CH}_{2} \mathrm{CH}=\mathrm{C}\left(\mathrm{CH}_{3}\right)_{2} \quad \mathrm{H}$

$9 \mathrm{H} \quad \mathrm{CH}_{2} \mathrm{CH}=\mathrm{C}\left(\mathrm{CH}_{3}\right)_{2}$

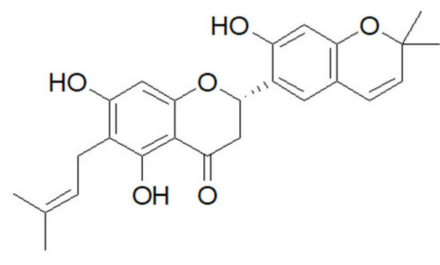

5

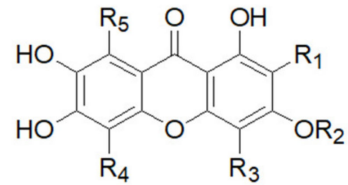

$$
\begin{aligned}
& \begin{array}{ccccc}
\mathrm{R}_{1} & \mathrm{R}_{2} & \mathrm{R}_{3} & \mathrm{R}_{4} & \mathrm{R}_{5} \\
10 \mathrm{C}\left(\mathrm{CH}_{3}\right)_{2} \mathrm{CH}=\mathrm{CH}_{2} & \mathrm{H} & \mathrm{H} & \mathrm{CH}_{2} \mathrm{CH}=\mathrm{C}\left(\mathrm{CH}_{3}\right)_{2} & \mathrm{H}
\end{array} \\
& 11 \mathrm{H} \quad \mathrm{H} \quad \mathrm{C}\left(\mathrm{CH}_{3}\right)_{2} \mathrm{CH}=\mathrm{CH}_{2} \quad \mathrm{H} \quad \mathrm{CH}_{2} \mathrm{CH}=\mathrm{C}\left(\mathrm{CH}_{3}\right)_{2} \\
& 12 \mathrm{C}\left(\mathrm{CH}_{3}\right)_{2} \mathrm{CH}=\mathrm{CH}_{2} \quad \mathrm{H} \quad \mathrm{CH}_{2} \mathrm{CH}=\mathrm{C}\left(\mathrm{CH}_{3}\right)_{2} \quad \mathrm{H} \quad \mathrm{H} \\
& 13 \mathrm{C}^{\mathrm{C}\left(\mathrm{CH}_{3}\right)_{2} \mathrm{CH}=\mathrm{CH}_{2} \mathrm{CH}_{3} \quad \mathrm{H}} \quad \mathrm{H} \quad \mathrm{H} \\
& 14 \mathrm{H} \quad \mathrm{H} \mathrm{C}\left(\mathrm{CH}_{3}\right)_{2} \mathrm{CH}=\mathrm{CH}_{2} \quad \mathrm{H} \quad \mathrm{H} \\
& 15 \mathrm{C}\left(\mathrm{CH}_{3}\right)_{2} \mathrm{CH}=\mathrm{CH}_{2} \quad \mathrm{CH}_{3} \quad \mathrm{CH}_{2} \mathrm{CH}=\mathrm{C}\left(\mathrm{CH}_{3}\right)_{2} \quad \mathrm{H} \quad \mathrm{H}
\end{aligned}
$$

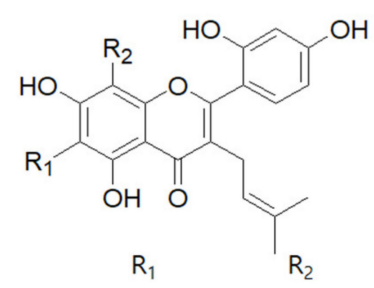

$6 \mathrm{CH}_{2} \mathrm{CH}=\mathrm{C}\left(\mathrm{CH}_{3}\right)_{2} \quad \mathrm{H}$

$7 \mathrm{H} \quad \mathrm{CH}_{2} \mathrm{CH}=\mathrm{C}\left(\mathrm{CH}_{3}\right)_{2}$<smiles>C=CC(C)(C)c1c2c(c3oc4cc(O)c(O)cc4c(=O)c3c1O)C=CC(C)(C)O2</smiles>

16

Figure 1. Structure of compounds 1-16.

Table 1. List of the 16 compounds evaluated in this study.

\begin{tabular}{cc}
\hline Compound & Name \\
\hline $\mathbf{1}$ & dihydrokaempferol \\
\hline $\mathbf{2}$ & steppogenin \\
\hline $\mathbf{3}$ & cudraflavanone D \\
\hline $\mathbf{4}$ & cudraflavanone B \\
\hline $\mathbf{6}$ & cudraflavanone A \\
\hline $\mathbf{7}$ & cudraflavone C \\
\hline $\mathbf{8}$ & kuwanon C \\
\hline $\mathbf{9}$ & cudraxanthone M \\
\hline 10 & cudraxanthone D \\
\hline 11 & cudraxanthone L \\
\hline 12 & cudratricusxanthone A \\
\hline 13 & macluraxanthone B \\
\hline 14 & $1,6,7-$ trihydroxy-2-(1,1-dimethyl-2-propenyl)-3-methoxyxanthone \\
\hline 15 & cudratricusxanthone L \\
\hline 16 & cudracuspixanthone A \\
\hline & cudratricusxanthone N \\
\hline
\end{tabular}




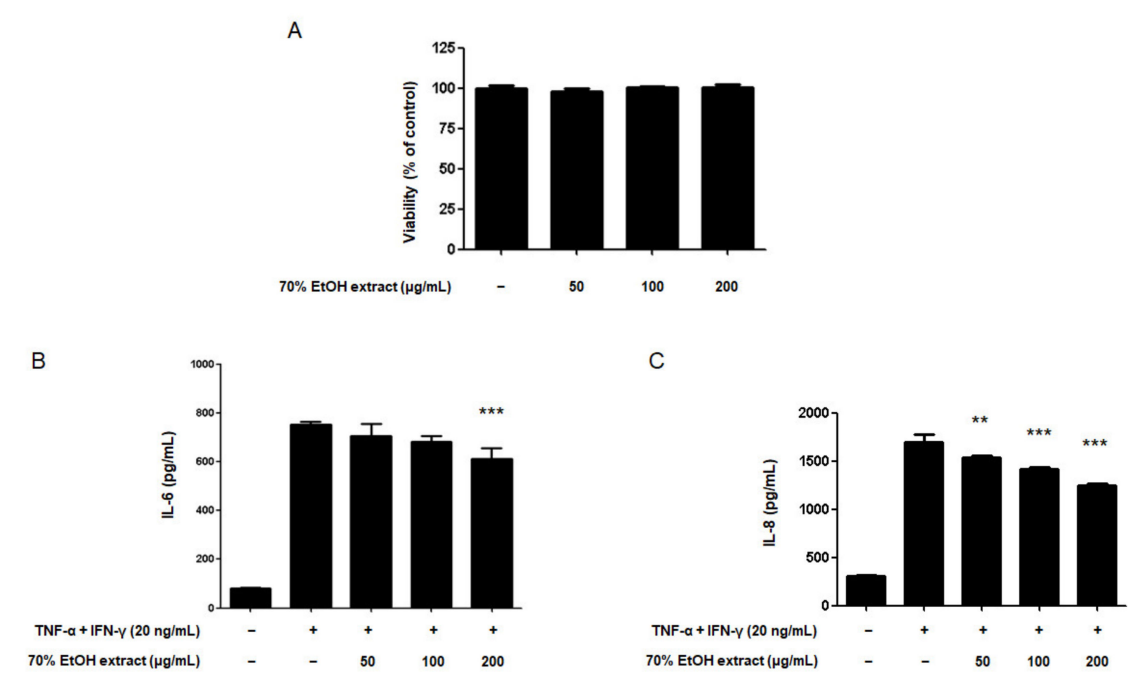

Figure 2. Effects of the $70 \% \mathrm{EtOH}$ extract from Cudrania tricuspidata on the viability of HaCaT cells (A) and, IL-6 (B) and IL-8 (C) production in HaCaT cells stimulated with TNF- $\alpha+$ IFN- $\gamma$. (A): The cells were incubated with the indicated concentrations for $24 \mathrm{~h}$; $(\mathbf{B})$ : cells were pre-treated with the $70 \% \mathrm{EtOH}$ extract for $3 \mathrm{~h}$ and stimulated with TNF- $\alpha+\mathrm{IFN}-\gamma$ for $24 \mathrm{~h}$. Each value represents the mean \pm SD. ${ }^{* *} p<0.01$ and ${ }^{* * *} p<0.001$ as compared with TNF- $\alpha+$ IFN- $\gamma$ only.

\subsection{Effect of the 16 Compounds from C. tricuspidata on the Viability of $\mathrm{HaCaT}$ Cells}

The cytotoxicity of the 16 compounds was evaluated using a Cell Counting Kit (CCK)8 assay on HaCaT cells. This assay is a sensitive colorimetric assay for the determination of cell viability in cell proliferation and cytotoxicity assays [32]. Initially, the cell toxicity of all compounds was evaluated at various concentration ranges (1 80 $\mu \mathrm{M}$; data not shown). The concentration values of all the tested compounds that did not result in cytotoxicity were determined, and then the cell viability was rechecked (Table 2). Therefore, these concentration values were used in subsequent experiments.

Table 2. Effects of the 16 compounds from C. tricuspidata on the viability of HaCaT cells.

\begin{tabular}{cccc}
\hline Compounds & Name & \multicolumn{2}{c}{ Cytotoxicity $(\boldsymbol{\mu M})$} \\
\hline $\mathbf{1}$ & dihydrokaempferol & $>80$ & $>80$ \\
$\mathbf{2}$ & steppogenin & $>80$ & $>80$ \\
$\mathbf{3}$ & cudraflavanone D & $>10$ & $>10$ \\
$\mathbf{4}$ & cudraflavanone B & $>20$ & $>20$ \\
$\mathbf{5}$ & cudraflavanone A & $>40$ & $>40$ \\
$\mathbf{6}$ & cudraflavone C & $>5$ & $>5$ \\
$\mathbf{7}$ & kuwanon C & $>40$ & $>40$ \\
$\mathbf{8}$ & cudraxanthone M & $>10$ & $>10$ \\
$\mathbf{9}$ & cudraxanthone D & $>5$ & $>5$ \\
$\mathbf{1 0}$ & cudraxanthone L & $>2$ & $>2$ \\
$\mathbf{1 1}$ & cudratricusxanthone A & $>5$ & $>5$ \\
$\mathbf{1 2}$ & macluraxanthone B & $>5$ & $>5$ \\
$\mathbf{1 3}$ & $1,6,7$-trihydroxy-2-(1,1-dimethyl-2-propenyl)-3- & $>40$ & $>40$ \\
$\mathbf{1 4}$ & methoxyxanthone & $>20$ & $>20$ \\
$\mathbf{1 5}$ & cudratricusxanthone L & $>2$ & $>2$ \\
$\mathbf{1 6}$ & cudracuspixanthone A & $>2$ & $>2$ \\
\hline
\end{tabular}

2.3. Effects of the 16 Compounds from C. tricuspidata on IL-6 Production in TNF- $\alpha+$ IFN- $\gamma$-Treated HaCaT Cells

The skin consists of two basic layers: the epidermis and dermis. The epidermis is mainly composed of keratinocytes [33]. Pro-inflammatory cytokines are known to play 
an important role in the immune response in keratinocytes [16]. Previous studies have reported the roles of TNF- $\alpha$ and IFN- $\gamma$ in inducing NF-KB activation, which upregulates the production of IL- 6 and IL-8 [25]. Initially, it was confirmed that the treatment with each of the compounds alone did not affect IL-6 production (Figure S1). Accordingly, the effect of the 16 compounds from C. tricuspidata on IL- 6 production in TNF- $\alpha+$ IFN- $\gamma$-treated $\mathrm{HaCaT}$ cells were determined. Briefly, $\mathrm{HaCaT}$ cells were pre-incubated with different concentrations of the 16 compounds for $3 \mathrm{~h}$, and then stimulated with TNF- $\alpha+$ IFN- $\gamma$ for $24 \mathrm{~h}$. The enzyme immunoassay results indicate that compounds $1,2,3,4,6,7,10,12,13$, 14, and 15 significantly decreased IL-6 production (Table 3, Figure S2). This suggested that some compounds isolated from C. tricuspidata could be a candidate material for inhibiting skin inflammation.

Table 3. Inhibitory effects of the 16 compounds on IL-6 and IL- 8 production in TNF- $\alpha+$ IFN- $\gamma$-treated HaCaT cells.

\begin{tabular}{|c|c|c|c|}
\hline \multirow{2}{*}{ Compounds } & \multirow{2}{*}{ Name } & \multicolumn{2}{|c|}{$\mathrm{IC}_{50}(\mu \mathrm{M})$} \\
\hline & & IL-6 & IL-8 \\
\hline 1 & dihydrokaempferol & $>80^{a}$ & $>80^{a}$ \\
\hline $2^{b}$ & steppogenin & $>80^{a}$ & $62.17 \pm 16.46^{\mathrm{a}}$ \\
\hline 3 & cudraflavanone D & $>10^{a}$ & $4.20 \pm 1.03^{\mathrm{a}}$ \\
\hline $4^{b}$ & cudraflavanone B & $>20^{a}$ & $9.88 \pm 3.22^{a}$ \\
\hline 5 & cudraflavanone A & $>40$ & $>40^{\mathrm{a}}$ \\
\hline $6^{\mathrm{b}}$ & cudraflavone C & $2.78 \pm 0.75^{\mathrm{a}}$ & $2.16 \pm 0.50^{\mathrm{a}}$ \\
\hline 7 & kuwanon C & $25.75 \pm 5.16^{a}$ & $>40^{a}$ \\
\hline 8 & cudraxanthone $\mathrm{M}$ & $>10$ & $>10^{a}$ \\
\hline 9 & cudraxanthone D & $>5^{a}$ & $>5^{a}$ \\
\hline 10 & cudraxanthone L & $>2^{a}$ & $>2^{a}$ \\
\hline 11 & cudratricusxanthone A & $>5$ & $>5$ \\
\hline $12^{b}$ & macluraxanthone B & $>5^{a}$ & $7.88 \pm 3.09^{a}$ \\
\hline $13^{b}$ & 1,6,7-trihydroxy-2-(1,1-dimethyl-2-propenyl)-3-methoxyxanthone & $9.69 \pm 2.15^{\mathrm{a}}$ & $3.87 \pm 0.96^{\mathrm{a}}$ \\
\hline $14^{\mathrm{b}}$ & cudratricusxanthone L & $9.86 \pm 0.92^{a}$ & $3.70 \pm 0.70^{\mathrm{a}}$ \\
\hline 15 & cudracuspixanthone A & $>2^{a}$ & $1.54 \pm 0.53^{\mathrm{a}}$ \\
\hline 16 & cudratricusxanthone $\mathrm{N}$ & $>2$ & $>2^{a}$ \\
\hline Positive control & curcumin & $11.96 \pm 3.13$ & $10.29 \pm 2.20$ \\
\hline
\end{tabular}

${ }^{\mathrm{a}}$ inhibitory effective compounds, $p<0.05 ;{ }^{\mathrm{b}}$ six selected compounds with the best inhibitory effect; the half maximal inhibitory concentration $\left(\mathrm{IC}_{50}\right)$.

\subsection{Effects of the 16 Compounds from C. tricuspidata on IL-8 Production in TNF- $\alpha+$ IFN- $\gamma$-Treated HaCaT Cells}

Next, the effect of the 16 compounds from C. tricuspidata on IL-8 production in $\mathrm{HaCaT}$ cells were determined. Briefly, HaCaT cells were pre-incubated with different concentrations of the 16 compounds for $3 \mathrm{~h}$. Thereafter, the cells were subjected to TNF- $\alpha+$ IFN- $\gamma$ stimulation for $24 \mathrm{~h}$. The enzyme immunoassay revealed that 15 compounds from $C$. tricuspidata, namely, compounds 1, 2, 3, 4, 5, 6, 7, 8, 9, 10, 12, 13, 14, 15 and 16, decreased IL-8 production in HaCaT cells (Table 3, Figure S3). Among the 16 compounds, 2, 6, 12, 13, 4 and $\mathbf{1 4}$ showed the most remarkable effect in inhibiting the production of both IL-6 and IL-8 in HaCaT cells (Footnote b in Table 3). Therefore, the most effective six compounds were selected for further experiments. Compound 2, with its flavanone skeletons, has been studied for its cyclooxygenase [33] and tyrosinase inhibitory effects [34-38]. In a previous study, compound 2 altered the anti-neuroinflammatory response in microglia [39]. Compound 6, a prenylated flavanone, has been reported to have apoptotic effects on A375.S2 melanoma cells [40] and to lead to the induction of apoptotic cell death in KM12, Caco-2, HT29, HCC2998, HCT116, and SW48 cell lines [41]. Compound 12, which is a prenylated xanthone, has been shown to exert anti-human immunodeficiency virus (HIV) [42], hepatoprotective [43], cytotoxic [44], and antitumor effects [45]. Compounds $\mathbf{1 3}$ and 14, which are prenylated xanthones, have only been shown to exert an NO production inhibitory effect in BV2 microglia [1]. In a previous study, compound 4, a prenylated flavanone, has exhibited anti-inflammatory and anti-neuroinflammatory effects in RAW264.7 and BV2 cells [46]. This is the first report on the biological action of compounds $\mathbf{2}, \mathbf{6}, \mathbf{1 2}, \mathbf{1 3}, \mathbf{4}$, and 
$\mathbf{1 4}$ on the inhibitory effects of skin inflammatory factors in skin HaCaT cells. Therefore, further mechanism studies of these six compounds in $\mathrm{HaCaT}$ cells were conducted.

\subsection{Effects of the Six Compounds from C. tricuspidata on RANTES and TARC Production by TNF- $\alpha+I F N-\gamma$-Treated HaCaT Cells}

Among the 16 compounds, the six most effective compounds were selected for further experiments on the production of the representative Th2 chemokines, RANTES (CCL5) and TARC (CCL17). The transport of Th2 cells to inflamed sites via CC chemokine receptor 4 (CCR4) is known to induce cell migration and invasion [47]. In many well-known skin immune diseases, an increase in the cytokine and chemokine levels is known as a biomarker of chronic inflammation; therefore, the suppression of these cytokines and chemokines may play a critical role in treating inflammatory skin diseases [48-50]. TNF- $\alpha$ and IFN- $\gamma$ have a major role in inducing NF- $\mathrm{KB}$ and STAT1 activation, which upregulates the expression of various chemokines, including MDC/CCL22, TARC/CCL17, RANTES/CCL5, and IL8 [51]. These chemokines or cytokines were elevated in the skin of patients and suggested as biomarkers for risk stratification of skin inflammation [52]. HaCaT cells were pre-incubated with different concentrations of the six compounds from C. tricuspidata for $3 \mathrm{~h}$. Thereafter, the cells were stimulated with TNF- $\alpha+$ IFN- $\gamma$ for $24 \mathrm{~h}$. The increased production of RANTES due to TNF- $\alpha+$ IFN- $\gamma$ treatment was found to be decreased by the pretreatment with all six compounds (Figure 3A). Similarly, TARC production induced by TNF- $\alpha+$ IFN- $\gamma(20 \mathrm{ng} / \mathrm{mL})$ was decreased by the pretreatment with all six compounds from $C$. tricuspidata (Figure 3B). Based on this result, it is considered that six compounds from $C$. tricuspidata have excellent inhibitory effects on the production of chemokines and cytokines. Therefore, by focusing on this point, further mechanism experiments were conducted using by six compounds.
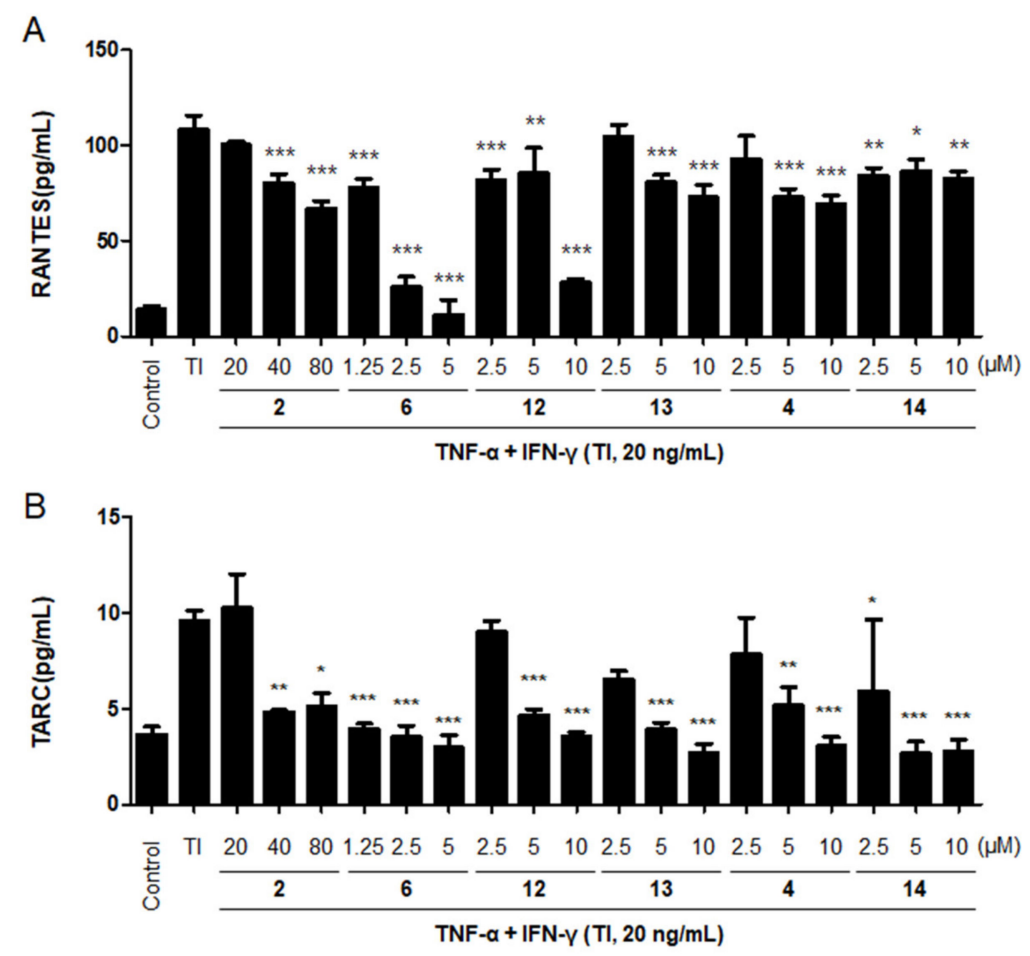

Figure 3. Effects of the six compounds from C. tricuspidata on RANTES (A) and TARC (B) production in TNF- $\alpha+$ IFN- $\gamma$-treated HaCaT cells. HaCaT cells were incubated with TNF- $\alpha+$ IFN- $\gamma(20 \mathrm{ng} / \mathrm{mL})$ in the presence or absence of the six compounds at the indicated concentrations. After $24 \mathrm{~h}$, the chemokine secretion levels were analyzed using enzyme-linked immunosorbent assay (ELISA). Data are presented as the mean \pm standard deviation. ${ }^{*} p<0.05,{ }^{* *} p<0.01$, and ${ }^{* *} p<0.001$ compared with TNF- $\alpha+$ IFN- $\gamma$ only. TI: TNF- $\alpha+$ IFN- $\gamma$. 
2.6. Effects of the Six Compounds from C. tricuspidata on COX-2 and ICAM-1 Protein Production by TNF- $\alpha+I F N-\gamma$-Treated HaCaT Cells

Intercellular adhesion molecule (ICAM)- 1 is upregulated in response to inflammatory mediators, such as the pro-inflammatory cytokines IL- $1 \beta$, TNF- $\alpha$, and IFN- $\gamma$ [36]. ICAM-1 is expressed in keratinocytes and is critical for the development of many skin diseases, such as contact dermatitis and lichen planus [53]. Cyclooxygenase (COX) is the enzyme responsible for the conversion of arachidonic acid to prostaglandin $\mathrm{H} 2$, which is the main step in the prostaglandin synthesis pathway. COX-2 expression plays a key role in skin inflammation [54]. In this experiment, the anti-inflammatory effects of the six compounds from C. tricuspidata on the expression of pro-inflammatory proteins were investigated in TNF- $\alpha+$ IFN- $\gamma$-treated HaCaT cells. Briefly, cells were pre-incubated for $3 \mathrm{~h}$ with or without the six compounds from $C$. tricuspidata $(5-80 \mu \mathrm{M})$ and were subsequently challenged with TNF- $\alpha+$ IFN- $\gamma(20 \mathrm{ng} / \mathrm{mL})$ for $24 \mathrm{~h}$. As shown in Figure $4 \mathrm{~A}, \mathrm{~B}$, compounds 6 and 14 decreased the expression level of COX-2. Previous studies have reported that compound 6 inhibits the expression of COX-2 [55]; however, this study is the first to report the inhibition of COX-2 protein production by compound 6 in $\mathrm{HaCaT}$ cells. In addition, cells were pre-incubated for $3 \mathrm{~h}$ with or without the six compounds from $C$. tricuspidata $(5-80 \mu \mathrm{M})$, and subsequently challenged with TNF- $\alpha+\operatorname{IFN}-\gamma(20 \mathrm{ng} / \mathrm{mL})$ for $6 \mathrm{~h}$. All six compounds significantly inhibited ICAM-1 expression in TNF- $\alpha+$ IFN- $\gamma-$ treated HaCaT cells (Figure 4C,D). Among the six compounds, compounds $\mathbf{6}$ and $\mathbf{1 4}$ were particularly effective in inhibiting COX-2 and ICAM-1 expression. These results suggest that compounds 6 and 14 could inhibit chemokines and cytokines by inhibiting COX-2 and ICAM-1 expression in skin cells.

A

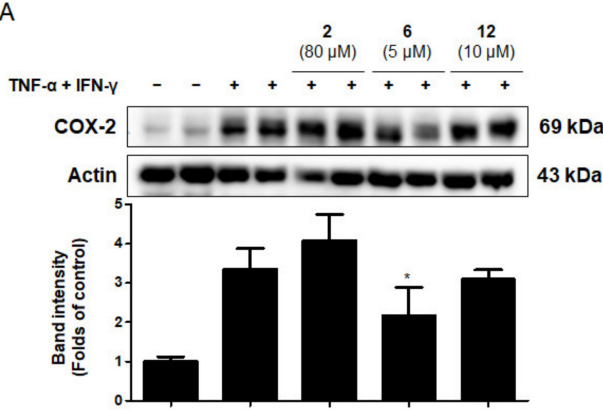

C

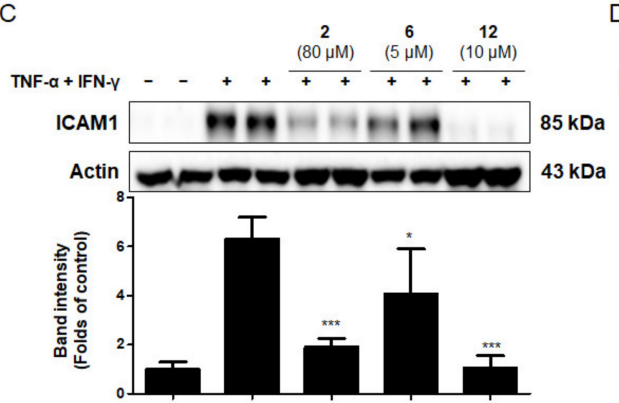

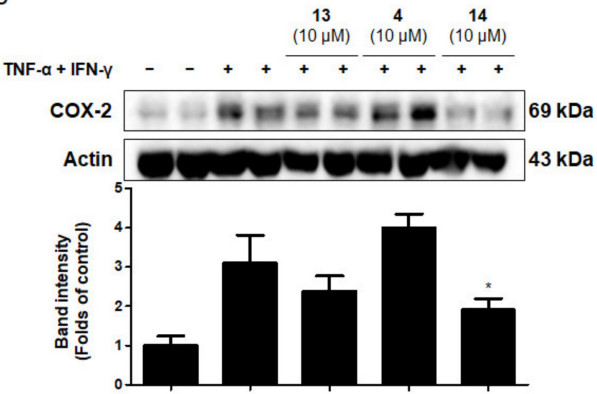

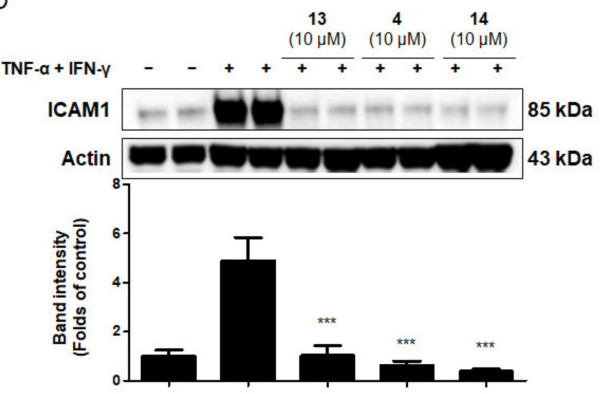

Figure 4. Protein expression levels of COX-2 (A,B) and ICAM-1 (C,D) in TNF- $\alpha+$ IFN- $\gamma$-treated HaCaT cells. (A,B) Cells were pretreated with the six compounds from $C$. tricuspidata at the indicated concentrations for $3 \mathrm{~h}$ and stimulated with TNF- $\alpha+\operatorname{IFN}-\gamma(20 \mathrm{ng} / \mathrm{mL})$ for $24 \mathrm{~h}$. (C,D) Cells were pretreated with the six compounds from $\mathrm{C}$. tricuspidata at the indicated concentrations for $3 \mathrm{~h}$, and then stimulated with TNF- $\alpha+\operatorname{IFN}-\gamma(20 \mathrm{ng} / \mathrm{mL})$ for $6 \mathrm{~h}$. Western blotting analysis was performed as described in the Materials and Methods section. Representative stains from four independent experiments are presented. The immunoblot was quantified using ImageJ software. The band intensity was normalized to that of actin. ${ }^{*} p<0.05,{ }^{* * *} p<0.001$ compared with TNF- $\alpha+$ IFN- $\gamma$ only. COX-2, cyclooxygenase-2; ICAM-1, intercellular adhesion molecule-1. 


\subsection{Effects of the Six Compounds from C. tricuspidata on NF- $\kappa B$ Activation in TNF- $\alpha+$ IFN- $\gamma$-Treated HaCaT Cells}

The activation of NF- $\kappa B$ by TNF- $\alpha$ and/or IFN- $\gamma$ results from high levels of IкB phosphorylation and the degradation of IкB in keratinocytes [29]. NF- $k B-$ mediated inflammation is a significant component of innate immunity and seems to be a final common pathway for the aggravation of the inflammatory response to stimuli in immune diseases of the skin [56]. To determine the potential mechanisms of the inhibition of TNF- $\alpha+$ IFN- $\gamma$-induced pro-inflammatory enzyme and the mediator levels by the six compounds from C. tricuspidata, their effects on the phosphorylation and degradation of cytoplasmic $\mathrm{I} \mathrm{K} B \alpha$ and on $\mathrm{p} 65$ translocation to the nucleus were investigated. Compounds $6, \mathbf{1 2}, \mathbf{1 3}, 4$ and 14 were found to inhibit the degradation of $\mathrm{I} \kappa \mathrm{B} \alpha$ in the cytoplasm (Figure $5 \mathrm{~A}, \mathrm{~B}$ ). In addition, compounds 13, 4, and 14 inhibited the phosphorylation of $I \kappa B \alpha$ (Figure 5C,D). When HaCaT cells were exposed to TNF- $\alpha+$ IFN- $\gamma$, NF-kB p65 translocated from the cytoplasm to the nucleus. Among the six compounds tested, five compounds $(\mathbf{2}, \mathbf{6}, \mathbf{1 2}, 4$ and 14) significantly inhibited NF- $\mathrm{kB}$ p65 translocation to the nucleus; however, compound 13 showed no significant effect (Figure 5E,F). These findings suggest that compounds 2, 6 , $12,13,4$ and 14 were useful in preventing skin inflammation, acting as NF- $\kappa B$ inhibitors. In particular, compounds $\mathbf{6}$ and 14 inhibited COX-2 and ICAM- 1 expression, and also significantly inhibited NF- $\mathrm{KB}$ p 65 translocation. Through this, these results suggest that compounds $\mathbf{6}$ and $\mathbf{1 4}$ have significantly affected in regulating of upstream signaling factors in skin inflammation.
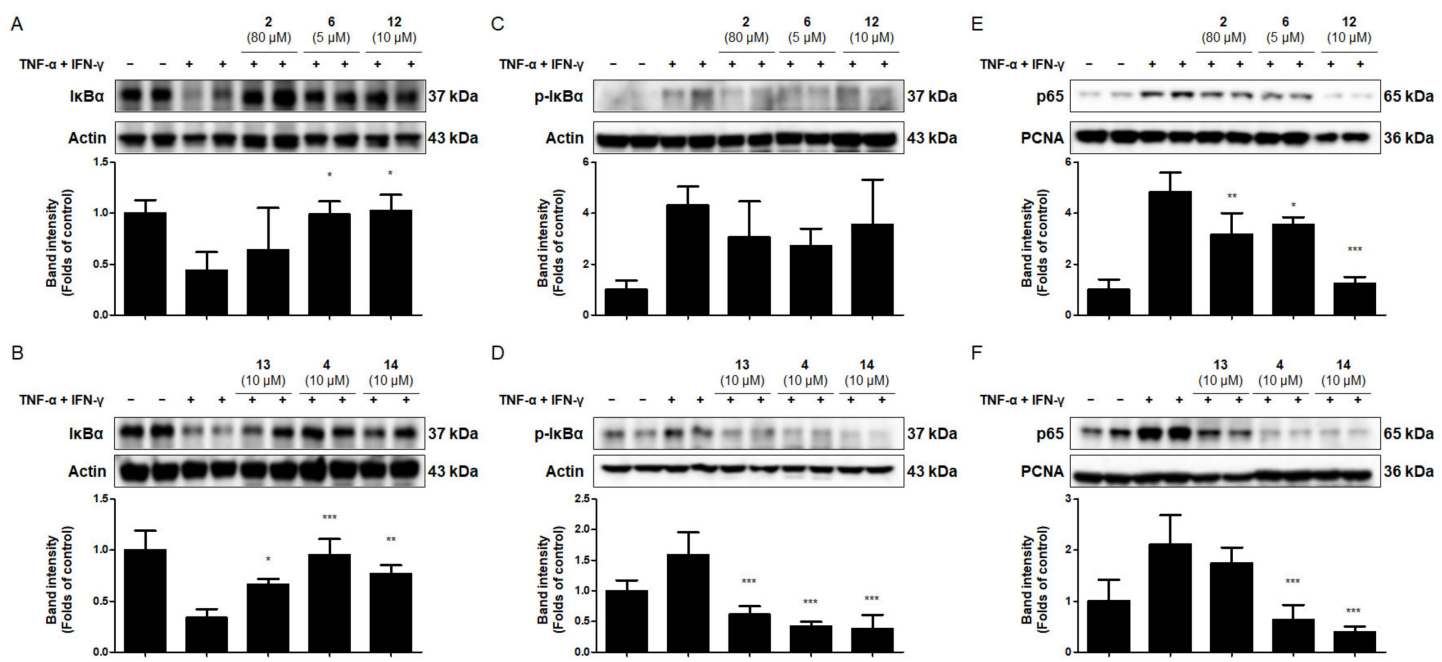

Figure 5. Effects of the six compounds from C. tricuspidata on the degradation of IKB- $\alpha(\mathbf{A}, \mathbf{B})$, the phosphorylation of IkB $\alpha$ (C,D), and the translocation of NF-kB p65 to the nucleus (E,F) in HaCaT cells. Cells were pretreated with the six compounds from $C$. tricuspidata at the indicated concentrations for $3 \mathrm{~h}$ and stimulated with TNF- $\alpha+\mathrm{IFN}-\gamma(20 \mathrm{ng} / \mathrm{mL})$ for $10 \mathrm{~min}$. $\mathrm{I} \kappa \mathrm{B} \alpha, \mathrm{p}-\mathrm{I} \kappa \mathrm{B} \alpha$, and NF- $\kappa \mathrm{B}$ p65 were analyzed using Western blotting, as described in the Materials and Methods section. Representative blots from four independent experiments are presented. The immunoblots were quantified using ImageJ software. The band intensity was normalized to that of actin or anti-proliferating cell nuclear antigen (PCNA). ${ }^{*} p<0.05$, ${ }^{* *} p<0.01,{ }^{* * *} p<0.001$ compared with TNF- $\alpha+$ IFN- $\gamma$ only.

2.8. Effects of the Six Compounds from C. tricuspidata on MAPK Phosphorylation in TNF- $\alpha+$ IFN- $\gamma$-Treated HaCaT Cells

Stimulation of keratinocytes with TNF- $\alpha+$ IFN- $\gamma$ upregulates various MAPK signaling pathways $[57,58]$. To evaluate the anti-inflammatory effects of the six compounds from C. tricuspidata on the MAPK pathway, Western blotting analysis was used to determine the phosphorylation levels of JNK1/2, ERK1/2, and p38 in TNF- $\alpha+$ IFN- $\gamma$-treated HaCaT cells. Cells were pretreated with the six compounds from $C$. tricuspidata at the indicated concentrations for $3 \mathrm{~h}$, and then stimulated with TNF- $\alpha+$ IFN- $\gamma(20 \mathrm{ng} / \mathrm{mL})$ for either 
$15 \mathrm{~min}, 2 \mathrm{~h}$, or $6 \mathrm{~h}$. Following the treatment with TNF- $\alpha+\mathrm{IFN}-\gamma$ for $2 \mathrm{~h}$, the phosphorylation of JNK1/2 was not inhibited by any of the six compounds (Figure 6A,B). After 15 min of treatment with TNF- $\alpha+$ IFN- $\gamma$, ERK1/2 phosphorylation was inhibited only by compound 14 (Figure 6C,D). The phosphorylation of p38 was inhibited only by compounds 13 and 4 after $6 \mathrm{~h}$ of treatment with TNF- $\alpha+$ IFN- $\gamma$ (Figure 6E,F). The potential of MAPKs activation to negatively regulate proinflammatory mediators has also been reported in some previous studies, in which ERK1/2 or p38 has been implicated as an anti-inflammatory signal [59,60]. Therefore, this study suggests that compound $\mathbf{1 4}, \mathbf{1 3}$ and $\mathbf{4}$ mediated ERK1/2 or p38 phosphorylation could serve as an important mechanism by which the compounds exerts its anti-inflammatory effects in skin cells. In addition, these results indicate that the compounds from $C$. tricuspidata inhibited TNF- $\alpha+$ IFN- $\gamma$-induced NF- $\mathrm{KB}$ and MAPK activation, as well as the production of cytokines and chemokines.
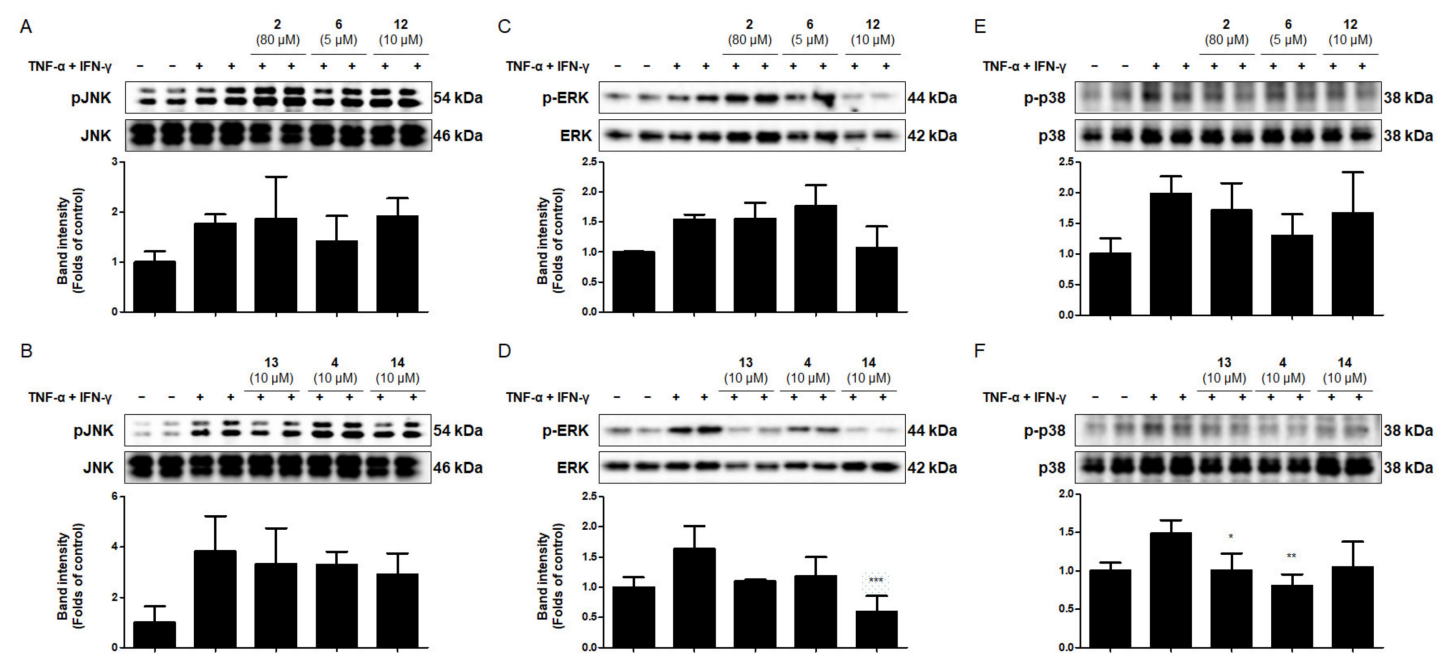

Figure 6. Effect of the six compounds from C. tricuspidata on JNK-1/2, ERK-1/2, and p38 phosphorylation in HaCaT cells. Cells were pretreated with the six compounds at the indicated concentrations for $3 \mathrm{~h}$, and then stimulated with TNF- $\alpha+\operatorname{IFN}-\gamma(20 \mathrm{ng} / \mathrm{mL})$ for $2 \mathrm{~h}(\mathbf{A}, \mathbf{B}), 15 \mathrm{~min}(\mathbf{C}, \mathbf{D})$, or $6 \mathrm{~h}(\mathbf{E}, \mathbf{F})$. Cell extracts were analyzed using Western blotting and antibodies specific for phosphorylated JNK1/2 (p-JNK1/2), p-ERK1/2, or p-p38. The membrane was stripped and reprobed to determine the total abundance of each MAPK, as a control measure. Representative blots from four independent experiments are presented. Immunoblots were quantified using ImageJ software. The band intensity was quantified and normalized to each total protein concentration. ${ }^{*} p<0.05$, ${ }^{* *} p<0.01$, and ${ }^{* * *} p<0.001$ compared with TNF- $\alpha+$ IFN- $\gamma$ only. JNK, c-Jun N-terminal kinase; ERK, extracellular signal regulatory kinase; MAPK, mitogen-activated protein kinase.

\section{Materials and Methods}

\subsection{Chemicals and Reagents for Cell Culture}

Phosphate-buffered saline (PBS), fetal bovine serum (FBS), penicillin, streptomycin, and DMEM + GlutaMAX ${ }^{\mathrm{TM}}$, which were used for cell culture, were purchased from Gibco (Grand Island, NY, USA). All other chemicals were purchased from Sigma-Aldrich (St. Louis, MO, USA). Primary antibodies, including anti-COX-2, anti-ICAM-1, anti-IkB $\alpha$, anti$\mathrm{p}-\mathrm{I} \kappa \mathrm{B} \alpha$, anti-p65, anti-actin, and anti-proliferating cell nuclear antigen, were purchased from Santa Cruz Biotechnology (Dallas, TX, USA), and anti-p-JNK, anti-JNK, anti-p-ERK, anti-ERK, anti-p-p38, and anti-p38 were purchased from Cell Signaling Technology (Danvers, MA, USA). Anti-rabbit and anti-mouse horseradish peroxidase-conjugated secondary antibodies were purchased from Millipore (Billerica, MA, USA). The isolation and structural determination of the 16 compounds from C. tricuspidata have been described elsewhere [31]. 


\subsection{Cell Culture}

HaCaT cells were donated by Hyeonsook Cheong, Chosun University (Kwangju, Korea). Cells $\left(5 \times 10^{6}\right.$ cells/dish) were seeded on 100 -mm dishes in DMEM + GlutaMAX ${ }^{\mathrm{TM}}$ containing streptomycin $(100 \mu \mathrm{g} / \mathrm{mL}), 10 \%$ heat-inactivated FBS, and penicillin $\mathrm{G}$ (100 units $/ \mathrm{mL}$ ), and then incubated at $37{ }^{\circ} \mathrm{C}$ in a humidified atmosphere $\left(5 \% \mathrm{CO}_{2}\right.$ and $95 \%$ air). TNF- $\alpha+\operatorname{IFN}-\gamma(20 \mathrm{ng} / \mathrm{mL})$ was used as negative control.

\subsection{CCK8 Assay}

To determine the viability of HaCaT cells, these were maintained at $2 \times 10^{4}$ cells/well, treated with the test compounds in the presence or absence of glutamate $(5 \mathrm{mM})$, and cultured for $24 \mathrm{~h}$. Subsequently, a CCK8 assay (Dojindo Laboratories, Kumamoto, Japan) was performed and the cells were incubated for $1 \mathrm{~h}$. The absorbance was then measured at $450 \mathrm{~nm}$.

\subsection{Enzyme-Linked Immunosorbent Assay (ELISA)}

The cytokines and chemokines in IL-6, IL-8, CCL17 (TARC), and CCL5 (RANTES) $\mathrm{HaCaT}$ cells were detected using an enzyme-linked immunosorbent assay. The levels of these cytokines and chemokines were measured using commercial ELISA kits (BioLegend, San Diego, CA, USA), according to the manufacturer's instructions.

\subsection{Western Blotting Analysis}

Cells were harvested and pelleted via centrifugation at $200 \times g$ for $3 \mathrm{~min}$, washed with PBS, and lysed in $20 \mathrm{mM}$ Tris- $\mathrm{HCl}$ buffer ( $\mathrm{pH}$ 7.4) containing a protease inhibitor mixture $(0.1 \mathrm{mM}$ phenylmethanesulfonyl fluoride, $5 \mathrm{mg} / \mathrm{mL}$ aprotinin, $5 \mathrm{mg} / \mathrm{mL}$ pepstatin $\mathrm{A}$, and $1 \mathrm{mg} / \mathrm{mL}$ chymostatin). The protein concentration was determined using a protein assay dye reagent concentrate (\#5000006; Bio-Rad Laboratories, Hercules, CA, USA). A total of 30 micrograms of protein from each sample was resolved using $7.5 \%$ and $12 \%$ sodium dodecyl sulfate-polyacrylamide gel electrophoresis. Thereafter, the proteins were electrophoretically transferred onto Hybond enhanced chemiluminescence (ECL) nitrocellulose membranes (Bio-Rad Laboratories). The membranes were blocked with $5 \%$ skimmed milk, and sequentially incubated with the relevant primary antibody and horseradish peroxidase-conjugated secondary antibody, prior to ECL detection (Pierce Biotechnology, Rockford, IL, USA).

\subsection{Preparation of the Cytosolic and Nuclear Fractions}

HaCaT cells were homogenized in PER-Mammalian Protein Extraction Buffer (1:20, w:v) (Pierce Biotechnology, Rockford, IL, USA) containing freshly added protease inhibitor cocktail I (EMD Biosciences, San Diego, CA, USA) and $1 \mathrm{mM}$ phenylmethanesulfonyl fluoride. The cytosolic fractions were prepared using centrifugation at $16,000 \times g$ for 5 min at $4{ }^{\circ} \mathrm{C}$, while the nuclear and cytoplasmic cell extracts were prepared using NE-PER nuclear and cytoplasmic extraction reagents, respectively (Pierce Biotechnology, Rockford, IL, USA).

\subsection{Statistical Analysis}

Data are expressed as the mean \pm standard deviation of three independent experiments. Statistical analysis was performed using GraphPad Prism software (version 5.01; GraphPad Software Inc., San Diego, CA, USA). The differences between means were assessed using one-way analysis of variance, followed by Tukey's multiple comparison test. A $p$ value $<0.05$ was used to indicate statistical significance.

\section{Conclusions}

In this study, the effects of 16 compounds from the roots of $C$. tricuspidata on skin inflammation were examined. Among the 16 compounds tested to decrease IL- 6 and IL- 8 production, the most effective six compounds, namely, steppogenin (2), cudraflavone C (6), 
macluraxanthone B (12), 1,6,7-trihydroxy-2-(1,1-dimethyl-2-propenyl)-3-methoxy xanthone (13), cudraflavanone B (4), and cudratricusxanthone L (14), were selected for subsequent experiments, and TNF- $\alpha+$ IFN- $\gamma$-induced RANTES, TARC, and ICAM-1 expression levels were decreased by the six compounds. However, only compounds 6 and 14 were found to reduce the expression levels of COX-2. Furthermore, the compounds 2, 6, 12, 4, and 14 significantly inhibited NF- $\kappa$ B p65 translocation to the nucleus. These results demonstrate that the compounds from $C$. tricuspidata could be further developed as therapeutic agents that suppress inflammation in human keratinocytes. These data may be used as the basis for the development of effective therapeutic strategies for skin inflammatory diseases.

Supplementary Materials: The following are available online at https:/ /www.mdpi.com/article/10 $.3390 /$ ijms22147472/s1.

Author Contributions: Conceptualization, W.K., N.K., E.-R.W. and D.-S.L.; data curation, W.K., H.L., N.K. and D.-S.L.; funding acquisition, E.-R.W. and D.-S.L.; investigation, W.K., H.L., N.K. and D.-S.L.; resources, Y.-C.K. and H.O.; supervision, E.-R.W., Y.-C.K., H.O. and D.-S.L.; visualization, W.K., N.K. and D.-S.L.; writing-original draft, W.K., N.K. and D.-S.L.; writing-review and editing, W.K. and D.-S.L. All authors have read and agreed to the published version of the manuscript.

Funding: This study was supported by a research fund (team research project) from Chosun University (2020).

Institutional Review Board Statement: Not applicable.

Informed Consent Statement: Not applicable.

Data Availability Statement: The data presented in this study are available on request from the corresponding author.

Conflicts of Interest: The authors declare no conflict of interest.

\section{References}

1. Yoon, C.S.; Kim, D.C.; Quang, T.H.; Seo, J.; Kang, D.G.; Lee, H.S.; Oh, H.; Kim, Y.C. A prenylated xanthone, cudratricusxan-thone a, isolated from Cudrania tricuspidata inhibits lipopolysaccharide-induced neuroinflammation through inhibition of NF- $\mathrm{kB}$ and p38 MAPK pathways in BV2 microglia. Molecules 2016, 21, 1240. [CrossRef] [PubMed]

2. Song, S.-H.; Ki, S.H.; Park, D.-H.; Moon, H.-S.; Lee, C.-D.; Yoon, I.-S.; Cho, S.-S. Quantitative Analysis, Extraction Optimization, and Biological Evaluation of Cudrania tricuspidata Leaf and Fruit Extracts. Molecules 2017, 22, 1489. [CrossRef]

3. Lee, H.; Ha, H.; Lee, J.K.; Seo, C.-S.; Lee, N.-H.; Jung, D.-Y.; Park, S.-J.; Shin, H.K. The Fruits of Cudrania tricuspidata Suppress Development of Atopic Dermatitis in NC/Nga Mice. Phytother. Res. 2011, 26, 594-599. [CrossRef]

4. Chon, I.J.; Lee, S.W.; Cha, J.H.; Han, J.H.; Whang, W.K. Anti-oxidant compounds of Cudrania tricuspidata leaves. Yakhak Hoeji 2005, $49,416-421$.

5. Lee, T.; Kwon, J.; Lee, D.; Mar, W.G. Effects of Cudrania tricuspidata fruit extract and its active compound, 5,7,3' $4^{\prime}$-tetrahydroxy6,8-diprenylisoflavone, on the high-affinity IgE receptor-mediated activation of syk in mast cells. J. Agric. Food Chem. 2015, 22, 5459-5467. [CrossRef] [PubMed]

6. Han, X.H.; Hong, S.S.; Hwang, J.S.; Jeong, S.H.; Hwang, J.H.; Lee, M.H.; Lee, M.K.; Lee, D.; Ro, J.S.; Hwang, B.Y. Monoamine oxidase inhibitory constituents from the fruits of Cudrania tricuspidata. Arch. Pharm. Res. 2005, 28, 1324-1327. [CrossRef] [PubMed]

7. Alghamdi, B.; Alghamdi, S.A. The neuroprotective role of melatonin in neurological disorders. J. Neurosci. Res. 2017, 96, 1136-1149. [CrossRef]

8. Uttarkar, S.; Brembilla, N.C.; Boehncke, W.-H. Regulatory cells in the skin: Pathophysiologic role and potential targets for anti-inflammatory therapies. J. Allergy Clin. Immunol. 2019, 143, 1302-1310. [CrossRef]

9. Buchholz, T.; Melzig, M.F. Polyphenolic compounds as pancreatic lipase inhibitors. Planta Med. 2015, 81, 771-783. [CrossRef]

10. Afrin, L.B.; Khoruts, A. Mast cell activation disease and microbiotic interactions. Clin. Ther. 2015, 37, 941-953. [CrossRef] [PubMed]

11. Ramsay, R.R.; Tipton, K.F. Assessment of enzyme inhibition: A review with examples from the development of monoamine oxidase and cholinesterase inhibitory drugs. Molecules 2017, 22, 1192. [CrossRef] [PubMed]

12. Kim, O.K.; Ho, J.N.; Nam, D.E.; Jun, W.J.; Lee, J.M. Anti-wrinkle activity of a Curdrania tricuspidata extract on ultravio-let-induced photoaging. J. Korean Soc. Food Sci. Nutr. 2013, 42, 608-614. [CrossRef]

13. Durazzo, A.; Lucarini, M.; Souto, E.B.; Cicala, C.; Caiazzo, E.; Izzo, A.A.; Novellino, E.; Santini, A. Polyphenols: A concise overview on the chemistry, occurrence, and human health. Phytother. Res. 2019, 33, 2221-2243. [CrossRef] [PubMed]

14. D'Andrea, G. Quercetin: A flavonol with multifaceted therapeutic applications? Fitoterapia 2015, 106, 256-271. [CrossRef] [PubMed] 
15. Mei, N.; Guo, X.; Ren, Z.; Kobayashi, D.; Wada, K.; Guo, L. Review of ginkgo biloba-induced toxicity, from experimental stud-ies to human case reports. J. Environ. Sci. Health C Environ. Carcinog. Ecotoxicol. Rev. 2017, 35, 1-28. [CrossRef] [PubMed]

16. Ahmadi, A.; Shadboorestan, A. Oxidative stress and cancer; the role of hesperidin, a citrus natural bioflavonoid, as a cancer chemoprotective agent. Nutr. Cancer 2016, 68, 29-39. [CrossRef] [PubMed]

17. Clementina, S.M.; Freitas, M.; Fernandes, E. A comprehensive review on xanthone derivatives as $\alpha$-glucosidase inhibitors. Eur. J. Med. Chem. 2018, 5, 1460-1479.

18. Fujimoto, T.; Hano, Y.; Nomura, T.; Uzawa, J. Components of Root Bark of Cudrania tricuspidata 2. Structures of Two New Isoprenylated Flavones, Cudraflavones A and B. Planta Med. 1984, 50, 161-163. [CrossRef]

19. Choi, H.J.; Kim, T.K.; Do, Y.; Rang, J. Physiological activities of Curdrania tricuspidata extracts on the skin. J. Korean Oil Chem. Soc. 2015, 32, 260-274. [CrossRef]

20. Habtemariam, S. The Nrf2/HO-1 Axis as Targets for Flavanones: Neuroprotection by Pinocembrin, Naringenin, and Eriodictyol. Oxidative Med. Cell. Longev. 2019, 2019, 1-15. [CrossRef] [PubMed]

21. Lee, I.K.; Song, G.S.; Kim, C.J.; Kim, H.M.; Oh, G.T.; Yue, Y.D. Tumor cell growth inhibition of cancer cell growth and antiox-idant activities of flavonoid compounds isolated from Curdrania tricuspidata. Appl. Biol. Chem. 1994, 37, $105-109$.

22. Pang, W.; Qi, X.; Cao, C.; Zhang, S. Inhibitory effects of TGP on KGF-induced hyperproliferation of HaCaT cells via sup-pression of the p38 MAPK/NF-кB p65 pathway. Mol. Med. Rep. 2018, 18, 2207-2215. [PubMed]

23. Sikandan, A.; Shinomiya, T.; Nagahara, Y. Ashwagandha root extract exerts anti-inflammatory effects in HaCaT cells by inhibiting the MAPK/NF-кB pathways and by regulating cytokines. Int. J. Mol. Med. 2018, 42, 425-434. [CrossRef] [PubMed]

24. Choi, H.J.; Lee, J.H.; Jung, Y.S. (+)-Nootkatone inhibits tumor necrosis factor $\alpha$ /interferon I-induced production of chemo-kines in HaCaT cells. Biochem. Biophys. Res. Commun. 2014, 447, 278-284. [CrossRef] [PubMed]

25. Yang, J.-H.; Hwang, Y.-H.; Gu, M.-J.; Cho, W.-K.; Ma, J.Y. Ethanol extracts of Sanguisorba officinalis L. suppress TNF- $\alpha /$ IFN- $\gamma-$ induced pro-inflammatory chemokine production in HaCaT cells. Phytomedicine 2015, 22, 1262-1268. [CrossRef] [PubMed]

26. Kong, L.; Liu, J.; Wang, J.; Luo, Q.; Zhang, H.; Liu, B.; Xu, F.; Pang, Q.; Liu, Y.; Dong, J. Icariin inhibits TNF- $\alpha /$ IFN- $\gamma$ induced inflammatory response via inhibition of the substance $\mathrm{P}$ and p38-MAPK signaling pathway in human keratinocytes. Int. Immunopharmacol. 2015, 29, 401-407. [CrossRef]

27. Henklova, P.; Vrzal, R.; Papouskova, B.; Bednar, P.; Jancova, P.; Anzenbacherova, E.; Ulrichova, J.; Maurel, P.; Pavek, P.; Dvorak, Z SB203580, a pharmacological inhibitor of p38 MAP kinase transduction pathway activates ERK and JNK MAP kinases in primary cultures of human hepatocytes. Eur. J. Pharmacol. 2008, 593, 16-23. [CrossRef]

28. Plotnikov, A.; Zehorai, E.; Procaccia, S.; Seger, R. The MAPK cascades: Signaling components, nuclear roles and mechanisms of nuclear translocation. Biochim. Biophys. Acta (BBA) Bioenergy 2011, 1813, 1619-1633. [CrossRef]

29. Sha, W.C. Regulation of immune responses by NF-kappa B/Rel transcription factor. J. Exp. Med. 1998, 187, 143-146. [CrossRef] [PubMed]

30. Barkett, M.; Gilmore, T.D. Control of apoptosis by Rel/NF-kB transcription factors. Oncogene 1999, 18, 6910-6924. [CrossRef]

31. Quang, T.H.; Ngan, N.T.T.; Yoon, C.-S.; Richomme, P.; Kang, D.G.; Lee, H.S.; Kim, Y.-C.; Oh, H. Protein Tyrosine Phosphatase 1B Inhibitors from the Roots of Cudrania tricuspidata. Molecules 2015, 20, 11173-11183. [CrossRef] [PubMed]

32. Wu, J.-L.; Wang, Y.-G.; Gao, G.-M.; Feng, L.; Guo, N.; Zhang, C.-X. Overexpression of lncRNA TCL6 promotes preeclampsia progression by regulating PTEN. Eur. Rev. Med. Pharmacol. Sci. 2019, 23, 4066-4072. [PubMed]

33. Su, B.-N.; Cuendet, M.; Hawthorne, M.E.; Kardono, L.B.S.; Riswan, S.; Fong, H.H.S.; Mehta, R.G.; Pezzuto, J.M.; Kinghorn, A.D. Constituents of the bark and twigs of Artocarpus dadah with cyclooxygenase inhibitory activity. J. Nat. Prod. 2002, 65, 163-169. [CrossRef]

34. Zheng, Z.P.; Cheng, K.W.; To, J.T.; Li, H.; Wang, M. Isolation of tyrosinase inhibitors from Artocarpus heterophyllus and use of its extract as antibrowning agent. Mol. Nutr. Food. Res. 2008, 52, 1530-1538. [CrossRef] [PubMed]

35. Zheng, Z.-P.; Tan, H.-Y.; Chen, J.; Wang, M. Characterization of tyrosinase inhibitors in the twigs of Cudrania tricuspidata and their structure-activity relationship study. Fitoterapia 2013, 84, 242-247. [CrossRef]

36. Jin, Y.J.; Lin, C.C.; Lu, T.M.; Li, J.H.; Chen, I.S.; Kuo, Y.H.; Ko, H.H. Chemical constituents derived from Artocarpus xantho-carpus as inhibitors of melanin biosynthesis. Phytochemistry 2015, 117, 424-435. [CrossRef]

37. Nguyen, H.X.; Nguyen, N.T.; Nguyen, M.H.; Le, T.H.; Van Do, T.N.; Hung, T.M.; Nguyen, M.T. Tyrosinase inhibitory activi-ty of flavonoids from Artocarpus heterophyllous. Chem. Cent. J. 2016, 10, 2. [CrossRef]

38. Zhang, L.; Tao, G.; Chen, J.; Zheng, Z.-P. Characterization of a New Flavone and Tyrosinase Inhibition Constituents from the Twigs of Morus alba L. Molecules 2016, 21, 1130. [CrossRef]

39. Kim, D.C.; Quang, T.H.; Oh, H.; Kim, Y.C. Steppogenin Isolated from Cudrania tricuspidata shows antineuroinflammatory effects via NF-kappaB and MAPK pathways in LPS-Stimulated BV2 and primary rat microglial cells. Molecules 2017, 22, 2130. [CrossRef]

40. Lee, C.-W.; Yen, F.-L.; Ko, H.-H.; Li, S.-Y.; Chiang, Y.-C.; Lee, M.-H.; Tsai, M.-H.; Hsu, L.-F. Cudraflavone C Induces Apoptosis of A375.S2 Melanoma Cells through Mitochondrial ROS Production and MAPK Activation. Int. J. Mol. Sci. 2017, 18, 1508. [CrossRef]

41. Soo, H.-C.; Chung, F.F.-L.; Lim, K.-H.; Yap, V.A.; Bradshaw, T.D.; Hii, L.-W.; Tan, S.-H.; See, S.-J.; Tan, Y.-F.; Leong, C.-O.; et al. Cudraflavone C Induces Tumor-Specific Apoptosis in Colorectal Cancer Cells through Inhibition of the Phosphoinositide 3-Kinase (PI3K)-AKT Pathway. PLoS ONE 2017, 12, e0170551. [CrossRef]

42. Groweiss, A.; Cardellina, J.H.; Boyd, M.R. HIV-Inhibitory prenylated xanthones and flavones from Maclura tinctoria. J. Nat. Prod. 2000, 63, 1537-1539. [CrossRef] [PubMed] 
43. Tian, Y.H.; Kim, H.C.; Cui, J.M.; Kim, Y.C. Hepatoprotective constituents of Cudrania tricuspidata. Arch. Pharm. Res. 2005, 28, 44-48. [CrossRef] [PubMed]

44. Lee, B.W.; Gal, S.W.; Park, K.-M. Cytotoxic Xanthones from Cudrania tricuspidata. J. Nat. Prod. 2005, 68, 456-458. [CrossRef] [PubMed]

45. Zou, Y.-S.; Hou, A.-J.; Zhu, G.-F. Isoprenylated Xanthones and Flavonoids from Cudrania tricuspidata. Chem. Biodivers. 2005, 2, 131-138. [CrossRef] [PubMed]

46. Ko, W.; Kim, K.W.; Quang, T.H.; Yoon, C.S.; Kim, N.; Lee, H.; Kim, S.C.; Woo, E.R.; Kim, Y.C.; Oh, H.; et al. Cudraflavanone $\mathrm{B}$ isolated from the root bark of Cudrania tricuspidata alleviates lipopolysaccharide-induced inflammatory responses by downregulating NF-KB and ERK MAPK signaling pathways in RAW264.7 macrophages and BV2 microglia. Inflammation 2021, 44, 104-115. [CrossRef] [PubMed]

47. Campbell, J.; Haraldsen, G.; Pan, J.; Rottman, J.; Qin, S.; Ponath, P.; Andrew, D.P.; Warnke, R.; Ruffing, N.; Kassam, N.; et al. The chemokine receptor CCR4 in vascular recognition by cutaneous but not intestinal memory T cells. Nat. Cell Biol. 1999, 400, 776-780. [CrossRef]

48. Ogawa, E.; Sato, Y.; Minagawa, A.; Okuyama, R. Pathogenesis of psoriasis and development of treatment. J. Dermatol. 2018, 45, 264-272. [CrossRef]

49. Kim, J.; Krueger, J.G. The Immunopathogenesis of Psoriasis. Dermatol. Clin. 2015, 33, 13-23. [CrossRef] [PubMed]

50. Furue, M.; Ulzii, D.; Vu, Y.H.; Tsuji, G.; Kido-Nakahara, M.; Nakahara, T. Pathogenesis of atopic dermatitis: Current para-digm. Iran J. Immunol. 2019, 16, 97-107.

51. Jeong, S.-J.; Lim, H.-S.; Seo, C.-S.; Jin, S.-E.; Yoo, S.-R.; Lee, N.; Shin, H.-K. Anti-inflammatory Actions of Herbal Formula Gyejibokryeong-Hwan Regulated by Inhibiting Chemokine Production and STAT1 Activation in HaCaT Cells. Biol. Pharm. Bull. 2015, 38, 425-434. [CrossRef]

52. Shimada, Y.; Takehara, K.; Sato, S. Both Th2 and Th1 chemokines (TARC/CCL17, MDC/CCL22, and Mig/CXCL9) are elevated in sera from patients with atopic dermatitis. J. Dermatol. Sci. 2004, 34, 201-208. [CrossRef]

53. Vejlsgaard, G.L.; Ralfkiaer, E.; Avnstorp, C. Kinetics and characterization of intercellular adhesion molecule-1 (ICAM-1) expression on keratinocytes in various inflammatory skin lesions and malignant lymphomas. J. Am. Acad. Dermatol. 1989, 20, 782-790. [CrossRef]

54. Chen, C.-C. Signal Transduction Pathways of Inflammatory Gene Expressions and Therapeutic Implications. Curr. Pharm. Des. 2006, 12, 3497-3508. [CrossRef] [PubMed]

55. Shaha, M.K.K.; Sirata, H.M.; Jamil, S.; Jalil, J. Flavonoids from the Bark of Artocarpus integer var. silvestris and their Antiinflammatory Properties. Nat. Prod. Commun. 2016, 11, 1275-1278. [PubMed]

56. Robert, C.; Kupper, T.S. Inflammatory Skin Diseases, T Cells, and Immune Surveillance. New Engl. J. Med. 1999, 341, 1817-1828. [CrossRef] [PubMed]

57. Sung, Y.-Y.; Kim, Y.S.; Kim, H.K. Illicium verum extract inhibits TNF- $\alpha$ - and IFN- $\gamma$-induced expression of chemokines and cytokines in human keratinocytes. J. Ethnopharmacol. 2012, 144, 182-189. [CrossRef]

58. Kim, S.Y.; Sohn, E.J.; Kim, D.W.; Jeong, H.J.; Kim, M.J.; Kang, H.W.; Shin, M.J.; Ahn, E.H.; Kwon, S.W.; Kim, Y.N.; et al. Transduced PEP-1-FK506BP Ameliorates Atopic Dermatitis in NC/Nga Mice. J. Investig. Dermatol. 2011, 131, 1477-1485. [CrossRef]

59. Funakoshi, M.; Tago, K.; Sonoda, Y.; Tominaga, S.; Kasahara, T. A MEK inhibitor, PD98059 enhances IL-1-induced NF-kappaB activation by the enhanced and sustained degradation of IkappaBalpha. Biochem. Biophys. Res. Commun. 2001, 283, 248-254. [CrossRef]

60. Xu, J.; Xiong, H.; Zhao, Z.; Luo, M.; Ju, Y.; Yang, G.; Mei, Z. Genistein suppresses allergic contact dermatitis through regulating the MAP2K2/ERK pathway. Food Funct. 2021, 12, 4556-4569. [CrossRef] 